\title{
MTHFR C677T Polymorphism and Risk of Ischemic Stroke in Kashmiri Population
}

\section{Nissar S ${ }^{1}$, Rasool R ${ }^{1}$, Bashir A $^{2}$ and Sameer AS}

${ }^{1}$ Departments of Immunology and Molecular Medicine, Sher-I-Kashmir Institute of Medical Sciences, Soura, Srinagar, Kashmir, India ${ }^{2}$ Department of Internal and Pulmonary Medicine, Sher-I-Kashmir Institute of Medical Sciences, Soura, Srinagar, Kashmir, India

${ }^{3}$ Department of Basic Medical Sciences, College of Medicine, King Saud Bin Abdulaziz University for Health Sciences, Jeddah, Kingdom of Saudi Arabia

\begin{abstract}
Methylenetetrahydrofolate reductase (MTHFR) is a critical enzyme in folate metabolism as it is involved in DNA synthesis, DNA repair and DNA methylation. One of the common functional polymorphisms of MTHFR is $677 \mathrm{C} \rightarrow \mathrm{T}$ which has been shown to impact various diseases, including stroke. To investigate the MTHFR C677T genotype frequency in stroke cases in the Kashmiri population, we designed a case- control study, where 70 stroke cases were studied for MTHFR C677T polymorphism against 160 controls taken from the general population employing the PCRRFLP technique. We found the frequency of the three different genotypes of MTHFR C677T in stroke case of Kashmiri population, i.e. CC, CT and TT, to be $71.4 \%, 17.1 \%$ and $11.4 \%$, as compared to healthy controls, where they were $75.6 \%, 16.9 \%$ and $7.5 \%$, respectively. There was no significant association between the MTHFR TT genotype and stroke. We conclude that the MTHFR C677T polymorphism is not involved in increasing the risk of stroke development in Kashmiri population.
\end{abstract}

Keywords: Stroke; MTHFR; Polymorphism; RFLP; Restriction digestion; Kashmir

\section{Introduction}

Methylenetetrahydrofolate reductase (MTHFR) is a key enzyme regulating the metabolism of folates, which are important nutrients required for both DNA synthesis as well as its methylation [1,2]. MTHFR irreversibly converts 5,10-methylenetetrahydrofolate to 5-methyltetrahydrofolate, the predominant circulating folate and the one-carbon donor for remethylation processes [3].

MTHFR C677T polymorphism is one of the most important polymorphisms regulating the function of MTHFR enzyme. This polymorphism results in an alanine-to-valine substitution at codon 222 of the protein [4], which has a profound effect on the biological activity MTHFR enzyme. It is known to drastically reduce the activity of the enzyme and also decrease its thermal stability [1]. Individuals with the variant $\mathrm{Val} / \mathrm{Val}$ genotype (TT) have no more than $30 \%$ of normal enzyme activity, and heterozygotes (CT) have $65 \%$ of normal enzyme activity $[4,5]$. The alanine-to-valine substitution also results in lower levels of 5-methyltetrahydrofolate, an accumulation of 5,10-methylenetetrahydrofolate increased plasma homocysteine levels and consequently homocysteinuria [4,6-9].

The MTHFR C677T polymorphism has been linked to various other diseases also like rheumatoid arthritis (RA) [10], coronary artery disease (CAD) [11], epilepsy [12] and Parkinson's disease [13]. Stroke is the second most common cause of death and disability worldwide. It is a multi factorial disease influenced by both environmental and genetic factors [14]. Several studies from around the globe have reported on the association of MTHFR C677T polymorphism and the risk of ischemic stroke. Many studies including few meta-analyses have found the homozygous TT variant form to be directly associated with the increased risk of stroke [15-19], but these studies do not conclude the association consistently and some studies have shown no association at all [20]. However, a recent meta-analysis by Li et al., [20] has suggested that MTHFR C667T genetic polymorphism to be significantly associated with increased risk of ischemic stroke.

A number of studies evaluating the role of MTHFR C677T polymorphism in the stroke patients have also been carried out in India, some studies failed to report anything conclusive [21,22] but a few studies however were able to report that the MTHFR C677T polymorphisms showed association with both homocysteine levels as well as stroke [23-26].

Since no such kind of study has been carried in Kashmiri population; therefore, we carried out a case-control study in our population to determine if this MTHFR C677T polymorphism is associated with an altered risk of ischemic stroke in our Kashmiri Population or not.

\section{Methodology}

\section{Subjects}

We chose 70 patients who were admitted in Sher I Kashmir Institute of Medical Sciences (SKIMS), Soura, Kashmir for the treatment of ischemic stroke. Chief complaints of studied patients included left / right sided weakness, altered sensorium and speech disturbances. Blood samples of 160 age- and sex-matched cases were also collected to serve as the external population controls for the study. The study was carried for the period of two years from March 2013 to March 2015.

Data on all stroke patients were obtained either from personal interviews with patients or from guardians, medical records. All patients and/or guardians were informed about the study and their will to participate in this study was taken on predesigned questionnaire (Available on request). The collection and use of samples for this study were previously approved by the SKIMS Ethics Committee.

\section{DNA extraction \& genotype analysis}

DNA extraction of the samples was performed by commercial DNA

*Corresponding author: Aga Syed Sameer, Department of Basic Medical Sciences College of Medicine, King Saud Bin Abdulaziz University for Health Sciences, King Abdulaziz Medical City, National Guard Health Affairs, P.O. Box: 9515, Jeddah Kingdom of Saudi Arabia, Tel: 966122246666; E-mail: agasy@ngha.med.sa; agas@ ksau-hs.edu.sa

Received July 04, 2015; Accepted August 22, 2015; Published August 25, 2015

Citation: Nissar S, Rasool R, Bashir A, Sameer As (2015) MTHFR C677T Polymorphism and Risk of Ischemic Stroke in Kashmiri Population. Hereditary Genet 4: 155. doi:10.4172/2161-1041.1000155

Copyright: (C) 2015 Nissar S, et al. This is an open-access article distributed under the terms of the Creative Commons Attribution License, which permits unrestricted use, distribution, and reproduction in any medium, provided the original author and source are credited. 
Citation: Nissar S, Rasool R, Bashir A, Sameer AS (2015) MTHFR C677T Polymorphism and Risk of Ischemic Stroke in Kashmiri Population. Hereditary Genet 4: 155. doi:10.4172/2161-1041.1000155

Page 2 of 4

extraction kit (Fermentas, USA). Previously reported primers: forward primer 5'-GGTCAGAAGCATATCAGTCATGAG-3' and the reverse primer 5'-CTGGGAAGAACTCAGCGAACTCAG-3', were used for the amplification of the 494-bp target region within the MTHFR gene [27].

PCR was carried out in a final volume of $25 \mu \mathrm{L}$ containing $50 \mathrm{ng}$ genomic DNA template, 1X PCR buffer (Biotools, Spain) with $2 \mathrm{mM}$ $\mathrm{MgCl}_{2}, 0.4 \mu \mathrm{M}$ of each primer (Genescript, India), $50 \mu \mathrm{M}$ dNTPs (Biotools, Spain), and 0.5 U DNA polymerase (Biotools, Spain). For PCR amplification, the standard program was used as follows: one initial denaturation step at $94^{\circ} \mathrm{C}$ for $7 \mathrm{~min}$, followed by 35 cycles of denaturation for $30 \mathrm{~s}$ at $94^{\circ} \mathrm{C}, 30 \mathrm{~s}$ of annealing at $58^{\circ} \mathrm{C}$, and $30 \mathrm{~s}$ of extension at $72^{\circ} \mathrm{C}$, followed by a final elongation cycle at $72^{\circ} \mathrm{C}$ for $5 \mathrm{~min}$.

For RFLP, the PCR product of MTHFR was digested with HinfI (2 $\mathrm{U}$ at $37^{\circ} \mathrm{C}$ for $16 \mathrm{~h}$ ) (Fermentas, USA). In the case of MTHFR C677T polymorphism, the Ala/Ala (CC) wild-type was identified by 394-bp and 100-bp bands, while the $\mathrm{Val} / \mathrm{Val}$ (TT) variant was identified by 229-bp, 165-bp and 100-bp bands and the heterozygous Ala/Val (CT) variant displayed all four bands (394 bp, $229 \mathrm{bp}, 165 \mathrm{bp}$ and $100 \mathrm{bp}$ ) (Figure 1). DNA fragments were electrophoresed through a $2-3 \%$ agarose gel for resolution.

\section{Statistical analysis}

Statistical analysis was performed by using SPSS Software (IBM). Observed frequencies of genotypes in stroke patients were compared to controls using chi-square or Fisher exact tests when expected frequencies were small. The chi-square test was used to verify whether genotype distributions were in Hardy-Weinberg equilibrium. Odds ratio was used to determine association between any of the recorded Clinico-epidemiological characteristics of patients with any one of the three genotypes of MTHFR gene. Statistical significance was considered when $\mathrm{p} \leq 0.05$.

\section{Results}

A total of 70 cases and 160 control subjects were included in this study with prior consent. Furthermore, out of 70 stroke cases, 45 were males and 25 cases were females $(\mathrm{M} / \mathrm{F}$ ratio=1.8), 42 were rural and 28 were urban and 38 were smokers and 32 were non-smokers (Table

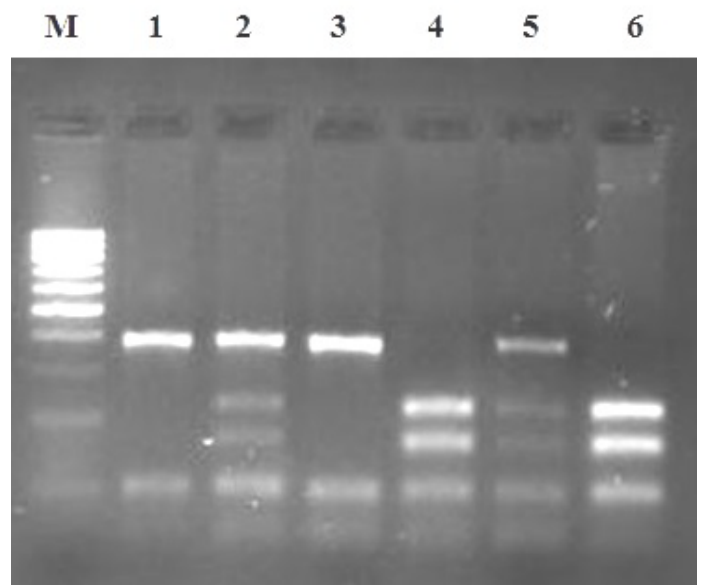

Note: 1) Lane M: 100-bp ladder. 2) Lanes 1 and 3 show wild-type (CC) form (394 bp and $100 \mathrm{bp}$ ). 3) Lanes 2 and 5 show heterozygous (CT) variant form (394 bp, 229 bp, 165 bp and 100 bp). 4) Lanes 4 and 6 show homozygous (TT) variant form (229 bp, $165 \mathrm{bp}$ and $100 \mathrm{bp}$ ).

Figure 1: Representative gel of MTHFR C677T polymorphism, representing amplicon digest with Hinfl (G|ANTC/CTNA|G); where variant (TT) is cleaved but not wild-type (CC).

\begin{tabular}{|c|c|c|c|}
\hline Variable & Cases $n=70$ & Controls $n=160$ & $P$-Value \\
\hline \multicolumn{4}{|l|}{ Age } \\
\hline$>50$ & 39 & 104 & \multirow{2}{*}{0.1} \\
\hline$\leq 50$ & 31 & 56 & \\
\hline \multicolumn{4}{|l|}{ Gender } \\
\hline Males & 45 & 88 & \multirow{2}{*}{0.1} \\
\hline Females & 25 & 72 & \\
\hline \multicolumn{4}{|l|}{ Dwelling } \\
\hline Rural & 42 & 104 & \multirow{2}{*}{0.5} \\
\hline Urban & 28 & 56 & \\
\hline \multicolumn{4}{|c|}{ Smoking Status } \\
\hline Ever & 38 & 85 & \multirow{2}{*}{0.8} \\
\hline Never & 32 & 75 & \\
\hline
\end{tabular}

Table 1: Frequency distribution analysis of selected demographic and risk factors in Stroke cases and controls.

\begin{tabular}{|c|c|c|c|c|}
\hline $\begin{array}{c}\text { MTHFR } \\
\text { Genotype }\end{array}$ & $\begin{array}{l}\text { Cases } \\
(n=70)\end{array}$ & $\begin{array}{l}\text { Controls } \\
(n=160)\end{array}$ & OR $(95 \% \mathrm{Cl}), P^{*}, F^{\psi}$ & $\begin{array}{l}X^{2}, P \text { Value } \\
\text { ( Overall) }\end{array}$ \\
\hline CC- (Wild) & $50(71.4 \%)$ & $121(75.6 \%)$ & 1 & \multirow{3}{*}{$0.98,0.6$} \\
\hline $\begin{array}{c}\text { CT - } \\
\text { (Heterozygous) }\end{array}$ & $12(17.1 \%)$ & $27(16.9 \%)$ & $1.07(0.5-2.2) 0.8,0$ & \\
\hline TT - (Variant) & $8(11.4 \%)$ & $12(7.5 \%)$ & $1.6(0.6-4.1), 0.32,0.44$ & \\
\hline
\end{tabular}

Table 2: Genotype frequencies of MTHFR gene polymorphism in stroke cases and controls.

1). Among control subjects, 88 were males and 72 were females $(M / F$ ratio=1.22). No significant gender- or age-related differences were observed between the groups ( $\mathrm{p}>0.05)$.

The frequency of Ala/Ala (CC), Ala/Val (CT) and Val/Val (TT) genotype in ischemic stroke cases were found to be $71.4 \%, 17.1 \%$ and $11.4 \%$, as compared to healthy controls, where they were $75.6 \%$, $16.9 \%$ and $7.5 \%$, respectively. There was not any varied difference in the genotype frequency of C677T MTHFR between ischemic stroke cases and the matched controls. So, this study suggests that there is no significant correlation between the $\mathrm{Val} / \mathrm{Val}(\mathrm{TT})$ variant of MTHFR gene and ischemic stroke in our Kashmiri population (Table 2).

\section{Discussion}

This is the first study to report on the association of MTHFR genotype with the risk of development of stroke in Kashmiri population, as data on MTHFR genotypes and susceptibility to ischemic stroke in our population did not exist at all. A number of studies have been reported across the globe on the modulation of risk of stroke by MTHFR C677T polymorphisms, because of the fact that plasma homocysteine (main substrate of MTHFR enzyme) levels are considered a major risk factor for various vascular diseases, including stroke $[28,29]$. This is because MTHFR plays a key role in regulating the homocysteine levels by utilizing it to make S-adenosyl methionine (SAM). A common C to T substitution in the MTHFR gene, at 677 nucleotide results in the conversion of alanine to valine in MTHFR enzyme [27] which in turn leads to reduction in the enzyme activity and decreased usage of homocysteine in cells thereby ensuing elevation of the plasma homocysteine level [21]. Hyperhomocysteinemia has many adverse effects including endothelial dysfunction with associated platelet activation and thrombus formation [30]. 
The MTHFR gene is centralized on chromosome $1 \mathrm{p} 36.22$ and is known to encompass $19.3 \mathrm{~kb}$ of DNA stretch 11 exons. The gene encodes $74.6-\mathrm{kD}$ protein composed of 656 amino acids [31]. MTHFR enzyme is cytosolic and catalyzes the conversion of 5,10-methylene tetrahydrofolate (THF) to 5-methylTHF, which in turn is used as cosubstrate for methionine synthesis and subsequent production of S-adenosyl methionine (SAM). MTHFR is also linked to the production of dTMP via thymidylate synthase and to purine synthesis and, therefore, plays a role in the provision of nucleotides essential for DNA synthesis [32]. Thus, any defect in the MTHFR gene will be reflected in a defect in the methylation pattern of DNA as well as in its synthesis. Chen et al. [33] has reported that the low activity of MTHFR 677TT genotype being advantageous as it ensures an adequate thymidylate pool for DNA synthesis when in folate sufficient cells.

In this molecular case-control study, C677T polymorphism in the MTHFR gene and its association with susceptibility to ischemic stroke were demonstrated. We demonstrated that MTHFR C677T gene polymorphism is not significantly associated with risk of ischemic stroke in Kashmiri population. We did not found any varied difference in the genotype frequency of C677T MTHFR between ischemic stroke cases and the matched controls. The frequency of Ala/Ala (CC), Ala/Val (CT) and Val/Val (TT) genotype in ischemic stroke cases were found to be $71.4 \%, 17.1 \%$ and $11.4 \%$, as compared to healthy controls, where they were $75.6 \%, 16.9 \%$ and $7.5 \%$ respectively. So, this study suggests that there is no significant correlation between the $\mathrm{Val} / \mathrm{Val}$ (TT) variant of MTHFR gene and ischemic stroke in our Kashmiri population. Our results are consistent with the previous study on the north Indian population [22].

Brattstrom et al. [34] in their meta-analyses of 13 case-control studies reported that the homozygous MTHFR 677TT individuals generally had fasting homocysteine levels higher than in heterozygous

\begin{tabular}{|c|c|c|c|c|}
\hline & MTHFR Genotype & Cases & Controls & $\begin{array}{l}\text { Significant } \\
\text { Association }\end{array}$ \\
\hline \multirow{4}{*}{$\begin{array}{l}\text { Our } \\
\text { Study } \\
2014\end{array}$} & & $(n=70)$ & $(n=160)$ & \\
\hline & CC- (Wild) & $50(71.4 \%)$ & $121(75.6 \%)$ & \multirow{3}{*}{ No } \\
\hline & CT - (Heterozygous) & $12(17.1 \%)$ & $27(16.9 \%)$ & \\
\hline & TT - (Variant) & $8(11.4 \%)$ & $12(7.5 \%)$ & \\
\hline \multirow{4}{*}{ [25] } & & $(n=120)$ & $(n=120)$ & \\
\hline & CC- (Wild) & $67(55.8 \%)$ & $90(75.0 \%)$ & \multirow{3}{*}{ Yes } \\
\hline & CT - (Heterozygous) & $49(40.8 \%)$ & $30(25.0 \%)$ & \\
\hline & TT - (Variant) & $4(3.3 \%)$ & $0(0.00 \%)$ & \\
\hline \multirow{4}{*}{ [22] } & & $(n=207)$ & $(n=188)$ & \\
\hline & CC- (Wild) & $137(66.2 \%)$ & $129(68.6 \%)$ & \multirow{3}{*}{ No } \\
\hline & CT - (Heterozygous) & $65(31.4 \%)$ & $54(28.7 \%)$ & \\
\hline & TT - (Variant) & $5(2.4 \%)$ & $5(2.7 \%)$ & \\
\hline \multirow{4}{*}{ [38] } & & $(n=84)$ & $(n=100)$ & \\
\hline & CC- (Wild) & $35(41.6 \%)$ & $60(60.0 \%)$ & \multirow{3}{*}{ Yes } \\
\hline & CT - (Heterozygous) & $43(51.2 \%)$ & $35(35.0 \%)$ & \\
\hline & TT - (Variant) & $6(7.2 \%)$ & $5(5.0 \%)$ & \\
\hline \multirow{4}{*}{ [16] } & & $(n=70)$ & $(n=50)$ & \\
\hline & CC- (Wild) & $26(37.1 \%)$ & $27(54.0 \%)$ & \multirow{3}{*}{ Yes } \\
\hline & CT - (Heterozygous) & $30(42.9 \%)$ & $20(40.0 \%)$ & \\
\hline & TT - (Variant) & $14(2.0 \%)$ & $3(6.0 \%)$ & \\
\hline \multirow{4}{*}{ [37] } & & $(n=72)$ & $(n=292)$ & \\
\hline & CC- (Wild) & $26(37.1 \%)$ & $27(54.0 \%)$ & \multirow{3}{*}{ Yes } \\
\hline & CT - (Heterozygous) & $30(42.9 \%)$ & $20(40.0 \%)$ & \\
\hline & TT - (Variant) & $14(2.0 \%)$ & $3(6.0 \%)$ & \\
\hline
\end{tabular}

Table 3: Genotype frequencies of MTHFR gene polymorphism in Stroke Cases and Controls.
MTHFR 677CT or normal individuals with MTHFR 677CC genotype. They also concluded that this polymorphism is only a modest risk factor for arterial thrombosis. A similar meta-analysis by Li et al. [35] found a statistically significant association of ischemic stroke with T allele of MTHFR gene, suggesting that the MTHFR C667T genetic polymorphism to be significantly associated with increased risk of ischemic stroke. Also, another meta-analysis by Kang et al. (19) found out that MTHFR C667T genetic polymorphism is associated with increased risk of hemorrhagic stroke, and the $\mathrm{T}$ allele may be an important risk factor for hemorrhagic stroke. Another recent study of Zhou et al. [36] in Chinese population also observed that MTHFR C677T gene polymorphism influences the risk of ischemic stroke by modulating serum homocysteine levels in individuals. Similar kinds of results implicating $\mathrm{T}$ allele of MTHFR in elevating the risk of ischemic stroke were reported by numerous researchers in their respective populations of varied racial background $[16,35,37,38]$ (Table 3). Klerk et al. [39] in their study on European Vs Asian population showed that the association between MTHFR C677T polymorphism and coronary heart disease was weaker among Europeans than that in Asian populations.

Therefore, we conclude that MTHFR C677T gene polymorphism is not significantly associated with risk of ischemic stroke in Kashmiri population.

\section{Acknowledgments}

This research was supported by the Sher-I-Kashmir Institute of Medical Sciences, Kashmir.

\section{References}

1. Cicek MS, Nock NL, Li L, Conti DV, Casey G, et al. (2004) Relationship between Methylenetetrahydrofolate Reductase C677T and A1298C Genotypes and Haplotypes and Prostate Cancer Risk and Aggressiveness. Cancer Epidemiol Biomarkers Prev 13: 1331-1336.

2. Lucock M (2000) Folic acid: nutritional biochemistry, molecular biology, and role in disease processes. Mol Genet Metab 71: 121-138.

3. Bailey LB, Gregory JF 3rd (1999) Polymorphisms of methylenetetrahydrofolate reductase and other enzymes: metabolic significance, risks and impact on folate requirement. J Nutr 129: 919-922.

4. Frosst P, Blom HJ, Milos R, Goyette P, Sheppard CA, et al. (1995) A candidate genetic risk factor for vascular disease: a common mutation in methylenetetrahydrofolate reductase. Nat Genet. 10: 111-113.

5. Kono, S and Chen K(2005) Genetic polymorphisms of methylenetetrahydrofolate reductase and colorectal cancer and adenoma. Cancer Sci 96: 535-542.

6. Nazki FH, Sameer AS, Ganaie BA (2014) Folate: metabolism, genes polymorphisms and the associated diseases. Gene 533: 11-20.

7. Bagley PJ, Selhub J (1998)A common mutation in the methylenetetrahydrofolate reductase gene is associated with an accumulation of formylated tetrahydrofolates in red blood cells. Proc Natl Acad Sci U S A 95: 13217-13220.

8. Mehlig K, Leander K, de Faire U, Nyberg F, Berg C, et al. (2013) The association between plasma homocysteine and coronary heart disease is modified by the MTHFR 677C>T polymorphism. Heart 99: 1761-1765.

9. Nienaber-Rousseau C, Ellis SM, Moss SJ, Melse-Boonstra A, Towers GW (2013) Gene-environment and gene-gene interactions of specific MTHFR, MTR and CBS gene variants in relation to homocysteine in black South Africans. Gene 530: 113-118.

10. Brambila-Tapia AJ, Duran-Gonzalez J, Sandoval-Ramirez L, Mena JP, Salazar Paramo M, et al. (2012) MTHFR C677T, MTHFR A1298C and OPG A163G polymorphisms in Mexican patients with rheumatoid arthritis and osteoporosis Dis Markers 109-114.

11. Ramkaran P, Phulukdaree A, Khan S, Moodley D, Chuturgoon AA (2015) Methylenetetrahydrofolate reductase C677T polymorphism is associated with increased risk of coronary artery disease in young South African Indians. Gene 571: 28-32.

12. Wu YL, Yang HY, Ding XX, Zhao X, Chen J, et al. (2014) Association between 
Citation: Nissar S, Rasool R, Bashir A, Sameer AS (2015) MTHFR C677T Polymorphism and Risk of Ischemic Stroke in Kashmiri Population. Hereditary Genet 4: 155. doi:10.4172/2161-1041.1000155

methylenetetrahydrofolate reductase $\mathrm{C} 677 \mathrm{~T}$ polymorphism and epilepsy susceptibility: a meta-analysis. Seizure 23: 411-416.

13. Zhu Y, Zhu RX, He ZY, Liu X, Liu HN (2015) Association of MTHFR C677T with total homocysteine plasma levels and susceptibility to Parkinson's disease: a meta-analysis. Neurol Sci 36: 945-951.

14. Kumar A, Sagar R, Kumar P, Sahu JK, Grover A, et al. (2013) Identification of genetic contribution to ischemic stroke by screening of single nucleotide polymorphisms in stroke patients by using a case control study design. BMC Neurol 13: 136

15. Sarecka-Hujar B, Kopyta I, Pienczk-Reclawowicz K, Reclawowicz D, EmichWidera E, et al. (2012) The TT genotype of methylenetetrahydrofolate reductase $677 \mathrm{C}>\mathrm{T}$ polymorphism increases the susceptibility to pediatric ischemic stroke: meta-analysis of the 822 cases and ,552 controls. Mol Biol Rep 39: 7957-7963.

16. Al-Allawi NA, Avo AS, Jubrael JM (2009) Methylenetetrahydrofolate reductase C677T polymorphism in Iraqi patients with ischemic stroke. Neurol India 57: 631-635.

17. Ariyaratnam R, Casas JP, Whittaker J, Smeeth L, Hingorani AD, et al. (2007) Genetics of ischaemic stroke among persons of non-European descent: meta-analysis of eight genes involving approximately ,500 individuals. PLoS Med 4: e131.

18. Li Z, Sun L, Zhang H, Liao Y, Wang D, et al. (2003) Elevated plasma homocysteine was associated with hemorrhagic and ischemic stroke, but methylenetetrahydrofolate reductase gene C677T polymorphism was a risk factor for thrombotic stroke: a multicenter case-control study in China. Stroke 34: $2085-2090$

19. Kang S, Zhao X, Liu L, Wu W, Zhang D (2013) Association of the C677T polymorphism in the MTHFR gene with hemorrhagic stroke: a meta-analysis. Genet Test Mol Biomarkers 17: 412-417

20. They-They TP, Battas O, Nadifi S (2013) Synergistic effect of MTHFR C677T and F2 G20210A polymorphisms on ischemic stroke. Neurosci Bull 29: 725-730.

21. Kumar A, Sagar R, Kumar P, Sahu JK, Grover A, et al. (2013) Identification of genetic contribution to ischemic stroke by screening of single nucleotide polymorphisms in stroke patients by using a case control study design. BMC Neurol 13: 136.

22. Somarajan BI, Kalita J, Mittal B, Misra UK (2011) Evaluation of MTHFR C677T polymorphism in ischemic and hemorrhagic stroke patients. A case-control study in a Northern Indian population. J Neurol Sci 304: 67-70.

23. Panigrahi I, Chatterjee T, Biswas A, Behari M, Choudhry PV, et al. (2006) Role of MTHFR C677T polymorphism in ischemic stroke. Neurol India 54: 48-50.

24. Banerjee I, Gupta V, Ganesh S (2007) Association of gene polymorphism with genetic susceptibility to stroke in Asian populations: a meta-analysis. J Hum Genet 52: 205-219.

25. Biswas A, Ranjan R, Meena A, Akhter MS, Yadav BK, et al. (2009) Homocystine levels, polymorphisms and the risk of ischemic stroke in young Asian Indians. J Stroke Cerebrovasc Dis 18: 103-110.

26. Yadav S, Hasan N, Marjot T, Khan MS, Prasad K, et al. (2013) Detailed analysis of gene polymorphisms associated with ischemic stroke in South Asians. PLoS One 8: e57305.

27. Sameer AS, Shah ZA, Nissar S, Mudassar S, Siddiqi MA (2011) Risk of colorectal cancer associated with the methylenetetrahydrofolate reductase (MTHFR) C677T polymorphism in the Kashmiri population. Genet Mol Res 10 1200-1210.

28. Wald DS, Law M, Morris JK (2002) Homocysteine and cardiovascular disease: evidence on causality from a meta-analysis. BMJ 325: 1202.

29. Homocysteine Studies Collaboration (2002) Homocysteine and risk of ischemic heart disease and stroke: a meta-analysis. JAMA 288: 2015-2022.

30. Welch GN, Loscalzo J (1998) Homocysteine and atherothrombosis. N Engl J Med 338: 1042-1050.

31. Saffroy R, Lemoine A, Debuire B (2005) MTHFR (10-Methylenetetrahydrofolate reductase). Atlas Genet Cytogenet Onco.

32. Wagner C (1995) Biochemical role of folate in cellular metabolism. In: Folate in Health and Disease, New York: Marcel Dekker.

33. Chen J, Giovannucci E, Kelsey K, Rimm EB, Stampfer MJ, et al. (1996) A methylenetetrahydrofolate reductase polymorphism and the risk of colorectal cancer. Cancer Res 56: 4862-4864.

34. Brattström L, Wilcken DE, Ohrvik J, Brudin L (1998) Common methylenetetrahydrofolate reductase gene mutation leads to hyperhomocysteinemia but not to vascular disease: the result of a metaanalysis. Circulation 98: 2520-2526.

35. Li P, Qin C (2014) Methylenetetrahydrofolate reductase (MTHFR) gene polymorphisms and susceptibility to ischemic stroke: a meta-analysis. Gene 535: 359-364.

36. Zhou BS, Bu GY, Li M, Chang BG, Zhou YP (2014) Tagging SNPs in the MTHFR gene and risk of ischemic stroke in a Chinese population. Int $\mathrm{J}$ Mol Sci 15: 8931-8940.

37. Mejia Mohamed EH, Tan KS, Ali JM, Mohamed Z (2011) TT Genotype of the Methylenetetrahydrofolate Reductase C677T Polymorphism is an Important Determinant for Homocysteine Levels in Multi-Ethnic Malaysian Ischaemic Stroke Patients. Ann Acad Med Singapore 40: 186-91.

38. Fekih-Mrissa N, Mrad M, Klai S, Mansour M, Nsiri B, et al. (2013) Methylenetetrahydrofolate Reductase (C677T and A1298C) Polymorphisms, Hyperhomocysteinemia, and Ischemic Stroke in Tunisian Patients. Journal of Stroke and Cerebrovascular Diseases 22: 465-469.

39. Klerk M, Verhoef P, Clarke R, Blom HJ, Kok FJ, et al. (2002) MTHFR 677C--> polymorphism and risk of coronary heart disease: a meta-analysis. JAMA 288: 2023-2031. 